\title{
Use of Wind Tunnel Measurements Data in Cold Launched Missile Flight Simulations
}

\section{Rafał Ożóg, Mariusz Jacewicz, Robert Głębocki}

Warsaw University of Technology, Faculty of Power and Aeronautical Engineering, Institute of Aeronautics and Applied Mechanics, Division of Mechanics, Nowowiejska 24, 00-665, Warsaw, Poland

\begin{abstract}
This article presents the results of wind tunnel testing of a model of a missile intended for a vertical cold launch system. The objective of this work was to obtain nondimensional aerodynamic coefficients to build a lookup table database for a six-degree-of-freedom numerical simulation of the missile launch phase. The material model of the full-scale missile was designed in UG/NX Siemens software and manufactured. Low speed measurements were conducted at the Warsaw University of Technology and as a result, static forces and moments characteristics were obtained using six component internal balance for a wide range of angles of attack and sideslip with a $1^{\circ}$ interval. Finally, 200 Monte-Carlo simulations in MATLAB/Simulink were evaluated to investigate the missile behavior in the launch phase with the measured results. It was observed that the rolling moment resulting, i.a. from fin cant angles misalignments in the initial roll rate of the missile significantly affects the trajectories.
\end{abstract}

Słowa kluczowe: wind tunnel, internal balance, missile, vertical cold launch, aerodynamic

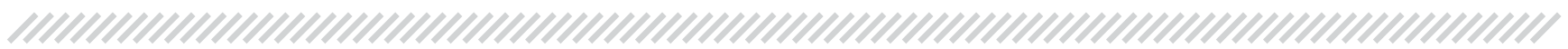

\section{Introduction}

This article presents the results of low velocity wind tunnel testing of the vertically cold launched missile model and applies them to the numerical simulation. The missile is launched vertically (Fig. 1) with an external device (e.g., hot gas generator, spring, elastic rope) with the velocity order several meters per second. Next, a set of small, mostly solid propellant, lateral thrusters is used to change the attitude rapidly. The main missile motor firing takes place out of the launch platform when the object has the desired attitude.

This approach has significant advantages over the classical hot vertical launching strategy, such as better firing coverage, lower acoustic, visual and thermal signatures [1]. It is worth mentioning that there are only a few missiles which have this launch capability, for example: 9M330, 9M96E, KM-SAM or CAMM. Moreover, aerodynamic data for existing cold launched missiles, especially at low speeds, are often classified and not widely available. At rough first approximation due to low dynamic pressure the aerodynamic loads acting on the object might be neglected [2]. On the other hand, there always exist some disturbances that might influence the missile trajectory. At the rapid turnover maneuver high angles of attacks might occur. In the literature

Autor korespondujący:

Mariusz |acewicz, mjacewicz@meil.pw.edu.pl

Artykuł recenzowany

nadesłany 18.11.2019 r., przyjęty do druku 08.01.2020 r. there are some examples of data for missiles at very low subsonic speeds [3. 4]. These characteristics must be known in advance in order to build an aerodynamic database for performing a six-degree-of-freedom (6 DoF) numerical simulation of the launch phase [5]. The abovementioned characteristics may be determined in different ways [6] using semi-empirical engineering level codes (e.g.: Missile DATCOM [7], AP97 [8], MISL3), Computational Fluid Dynamics, wind tunnel testing or identification from flight tests data. Wind tunnel experimental methodology was chosen in this work because it is one of the most reliable methods of obtaining aerodynamic characteristics. A serious disadvantage of this technique are relatively high costs. Therefore, it is important to plan a test program carefully in order to minimize the required number of test cases.

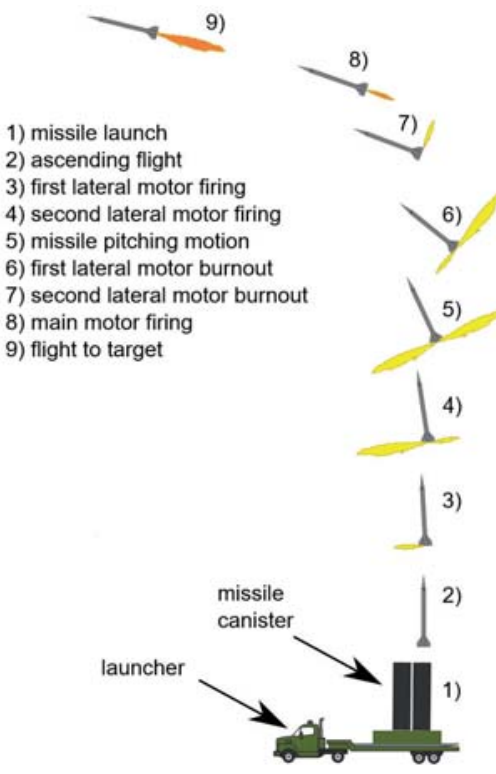

Fig. 1. Missile vertical cold launch

Rys. 1. Zimny pionowy start rakiety 


\section{Aerodynamic Model}

It is quite a difficult task to maintain full geometric, kinematic and dynamic similarities between flow around a real object and its scaled model during experiments. For the considered case, gravity and unsteady effects were assumed to be negligible. For this reason, Reynolds number Re and Mach number $M a$ were chosen as main similarity criteria for static measurements. The Reynolds number is

$$
R e=\frac{\rho V d}{\mu}
$$

where $\rho$ is air density, $V$ - characteristic flow velocity, $d$ - missile diameter and $\mu$ is dynamic viscosity. The Mach number is

$$
M a=\frac{V}{a}
$$

where $a$ is the speed of sound. When these nondimensional numbers are the same for the real and scaled flow then both flows will be dynamically similar and as a result, the force and moment coefficients will be the same for the model and full-scale flows.

Sometimes it might be impossible to match both numbers simultaneously. The required velocity for the flow in the experiment should be:

$$
V_{m}=\frac{\rho}{\rho_{m}} \frac{l}{l_{m}} \frac{\mu_{m}}{\mu} V
$$

where lowercase index $m$ refers to model parameters, and the quantities without the index refer to the full scale prototype.

Using a downscaled model to keep the Reynolds numbers equal, either the airspeed or air density must be increased. On the other hand, increasing the airspeed will also bring the Mach number to a high range, while the area of interest is $M a<<1$. In the considered low-speed flight region, Reynolds number effects predominate and matching of the Mach number is not so critical [6].

3D CAD modeling methodology in UG/NX Siemens software was used to design the test object. The virtual assembly was used for model elements machining. The resulting material model was $52.5 \%$ in size with respect to the full scale missile

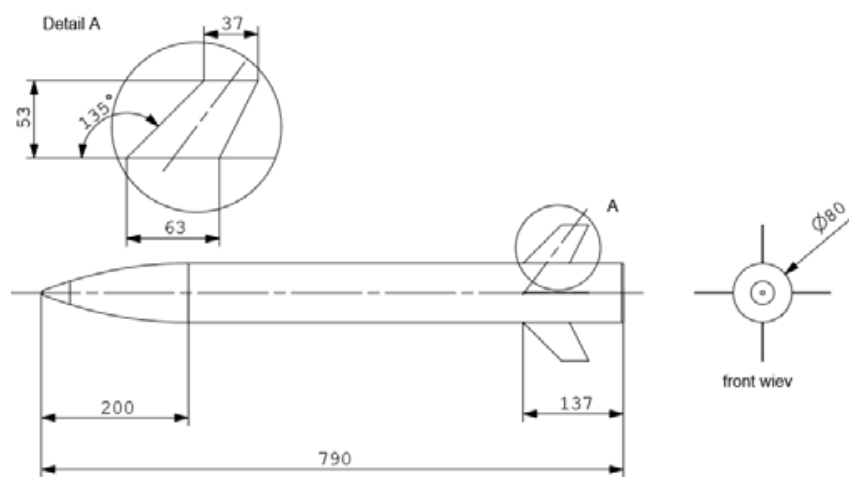

Fig. 2. Basic geometric characteristics of the missile model (dimensions in millimeters)

Rys. 2. Podstawowe charakterystyki geometryczne modelu rakiety (wymiary w milimetrach)

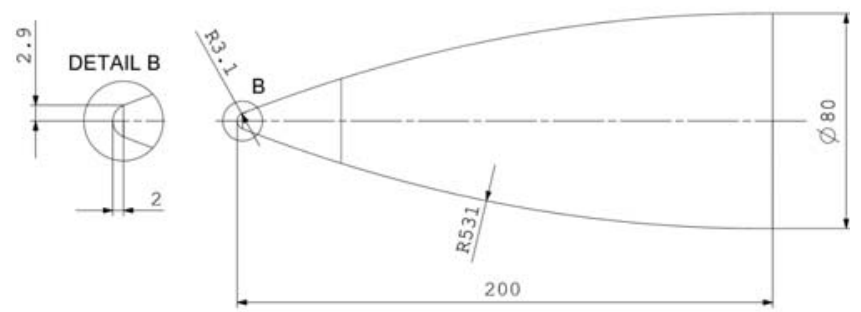

Fig. 3. Shape of the nose section (dimensions in millimeters) Rys. 3. Kształt części nosowej (wymiary w milimetrach)

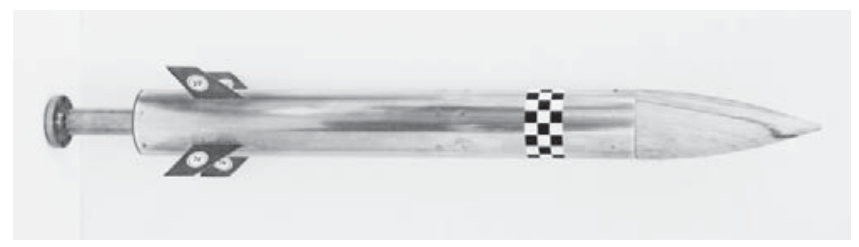

Fig. 4. Material model of the missile

Rys. 4. Model materialny rakiety

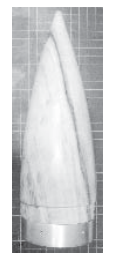

(a)

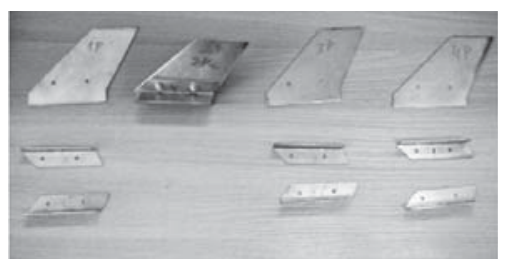

(b)

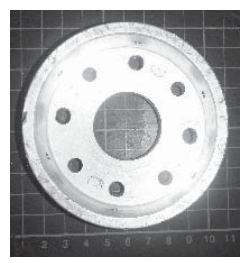

(c)
Fig. 5. Components of the model (a) nose section (b) fins (c) mounting frame

Rys. 5. Komponenty modelu (a) sekcja nosowa (b) stabilizatory (c) wręga mocująca

due to the limited volume of the wind tunnel test section. The shape of the model was presented in Fig. 2 and Fig. 3.

A spherically blunted tangent ogive nose section was applied. Flat plate airfoil (1.2 mm thick) was used in four trapezoidal fins rigidly mounted in cruciform configuration.

The material model (Fig. 4) was made of a wooden nose section, aluminum cylindrical body and steel fins. The surface of the model was polished to achieve the desired roughness. For the preliminary tests the model was mounted to the aerodynamic scale with the steel rear support.

A visual marker in the form of chessboard was added to observe potential model vibrations at high inflow angles. The mass of the model (without support) was approximately $2.3 \mathrm{~kg}$. Some of the model components are presented in Fig. 5.

\section{Experimental setup}

The tests were conducted in a subsonic closed circuit wind tunnel located at the Warsaw University of Technology (Fig. 6). The diameter of the circular open test section is $1.6 \mathrm{~m}$ and the maximum achievable flow speed is $50 \mathrm{~m} / \mathrm{s}$ [9]. The movable mounting allows continuous or step-by-step movement to investigate the aerodynamic characteristics in the range of $\pm 20^{\circ}$ angles of attack and sideslip. The series of initial tests for both "+" (roll angle $0^{\circ}$ ) and $x$ (roll angle $45^{\circ}$ ) stabilizer configurations were performed. Finally, the missile model was mounted in the "+" configuration with respect to the horizontal and vertical planes. 

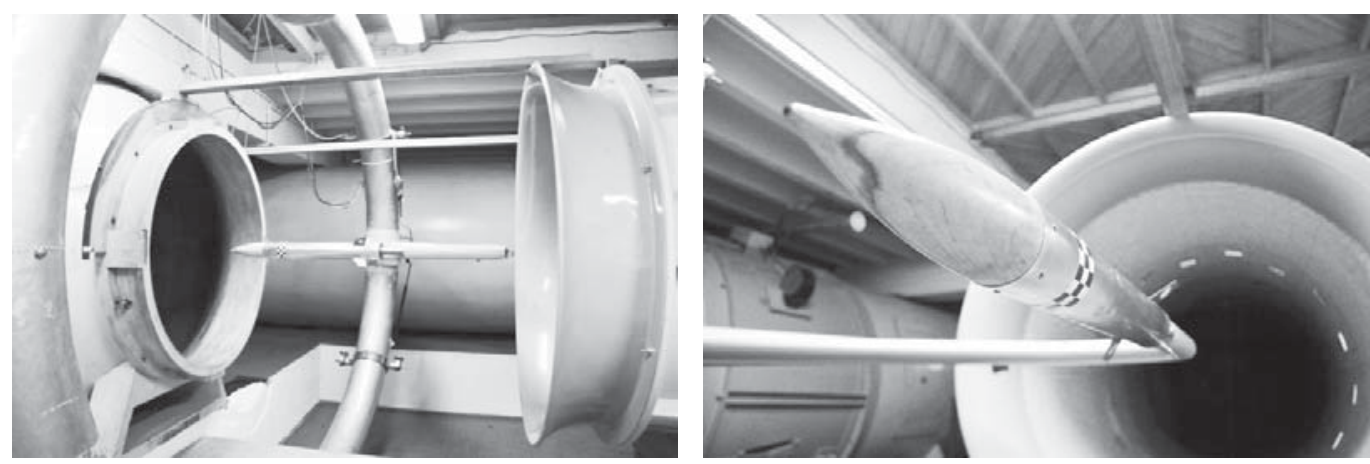

Fig. 6. Material model during preliminary wind tunnel measurements

Rys. 6. Model materialny w czasie wstępnych pomiarów wagowych

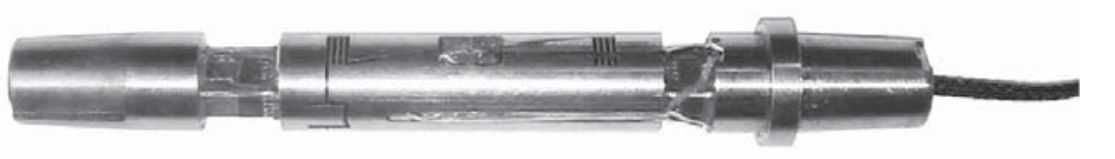

Fig. 7. Six-component aerodynamic internal balance

Rys. 7. Sześciokomponentowa aerodynamiczna waga wewnętrzna

Next the mounting interface was slightly modified and the six-component aerodynamic internal balance (Fig. 7) was used to measure the forces and moments which act on the model.

Various coordinate systems [10] were used during the experiment (Fig. 8). The positive sign convention was marked with the pink arrows.

The aerodynamic loads were measured in the body-fixed coordinate system $O_{b} x_{b} y_{b} z_{b}$. The dynamic pressure was $1 \mathrm{~Pa}$. The flow velocity was obtained from the measured dynamic pressure and was equal to $34.5 \mathrm{~m} / \mathrm{s}$. The mean flow temperature in the test section was $28{ }^{\circ} \mathrm{C}$, Mach number 0.1 and Reynolds number 120,000 . These conditions correspond to the flow velocity around a full scale missile $\sim 17 \mathrm{~m} / \mathrm{s}$ (the beginning of the powered flight phase).

The tests were conducted for angles of attack from the range $-20^{\circ} \leq \alpha \leq 20^{\circ}$ and sideslip angles $-20^{\circ} \leq \beta \leq 5^{\circ}$ with $1^{\circ}$ step size (for both parameters). The missile has cruciform symmetry. Therefore, measuring loads from the above region allow quick approximation of larger positive angles of sideslip. A fully automatic laboratory test stand was used to acquire the results (Fig. 9).

The presence of the balance could dramatically disturb the obtained results, especially the axial force coefficient. The twosteps method was used to overcome this difficulty in order to measure the loads properly and ensure high accuracy of data. At first the model with external flow was tested. Next, measurements with no flow were performed to obtain tare weight. Finally, to obtain pure aerodynamic loads acting on the model, the no flow load was subtracted from the results with flow.

The nondimensional aerodynamic force coefficients [11] in body fixed frame $O_{b} x_{b} y_{b} z_{b}$ were obtained with the formulas:

$$
\begin{gathered}
C_{X}=\frac{2 X_{a 0}}{\rho V_{0}^{2} S_{m}} \\
C_{Y}=\frac{2 Y_{a 0}}{\rho V_{0}^{2} S_{m}} \\
C_{Z}=\frac{2 Z_{a 0}}{\rho V_{0}^{2} S_{m}}
\end{gathered}
$$

where $X_{a 0}, Y_{a 0}, Z_{a 0}$ are the measured forces. $C_{X}, C_{Y}, C_{Z}$ are axial, side and normal forces nondimensional coefficients, is air density, $V_{0}$ is flow velocity, $S_{m}=\pi d_{m}^{2} / 4$ is the model cross section area and $d_{m}$ is the model diameter.

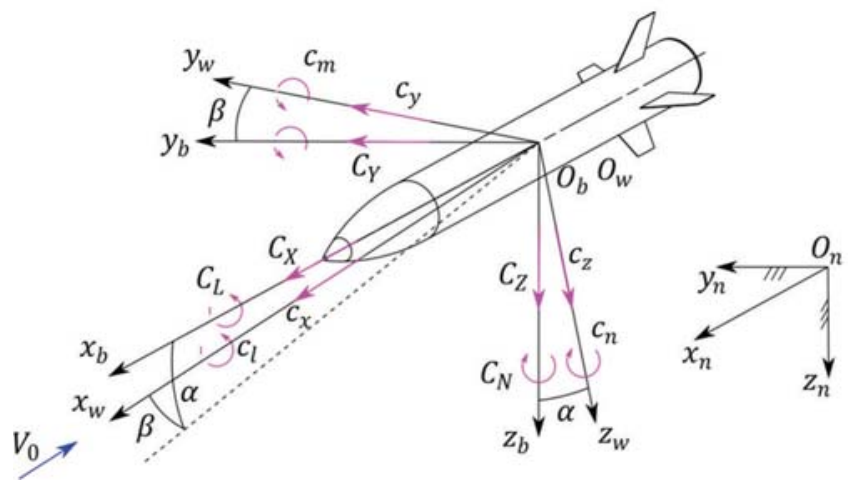

Fig. 8. Coordinate systems used in the experiment Rys. 8. Układy współrzędnych użyte w eksperymencie

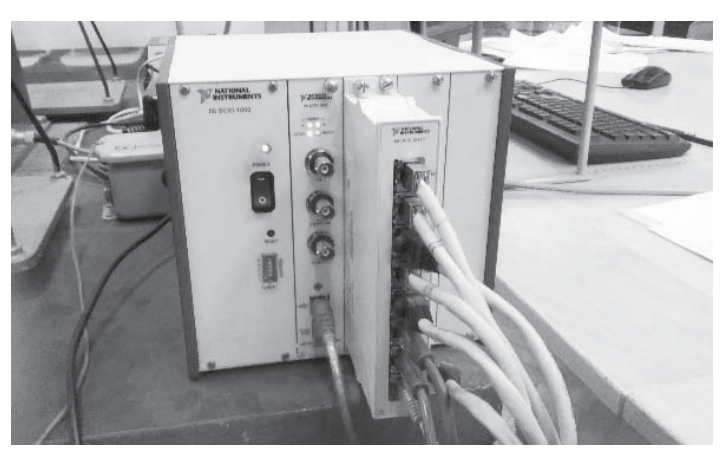

Fig. 9. Measurement device with a strain/bridge input module Rys. 9. Układ pomiarowy z modułem wejściowym 
In a similar way, the moment coefficients were calculated as:

$$
\begin{gathered}
C_{L}=\frac{2 L_{a 0}}{\rho V_{0}^{2} S_{m} d_{m}} \\
C_{M}=\frac{2 M_{a 0}}{\rho V_{0}^{2} S_{m} d_{m}} \\
C_{N}=\frac{2 N_{a 0}}{\rho V_{0}^{2} S_{m} d_{m}}
\end{gathered}
$$

where $L_{a 0}, M_{a 0}, N_{a 0}$ are the measured moments. $C_{L}, C_{M}, C_{N}$ are rolling, pitching and yawing moments coefficients. The moments were measured about the point located $0.3 \mathrm{~m}$ from the missile base. Standard corrections for open test sections presented in [12] were partially applied to postprocess the results.

\section{Results and Discussion}

To present the data in the most intuitive and readable manner, the measured data were converted from body fixed $O_{b} x_{b} y_{b} z_{b}$ to wind axes $O_{w} x_{w} y_{w} z_{w}$ with the expressions [11]:

$$
\left[\begin{array}{c}
c_{x} \\
c_{y} \\
c_{z}
\end{array}\right]=\left[\begin{array}{ccc}
\cos \alpha \cos \beta & \sin \beta & \sin \alpha \cos \beta \\
-\cos \alpha \sin \beta & \cos \beta & -\sin \alpha \sin \beta \\
-\sin \alpha & 0 & \cos \alpha
\end{array}\right]\left[\begin{array}{l}
C_{X} \\
C_{Y} \\
C_{Z}
\end{array}\right]
$$

$\left[\begin{array}{c}c_{l} \\ c_{m} \\ c_{n}\end{array}\right]=\left[\begin{array}{ccc}\cos \alpha \cos \beta & \sin \beta & \sin \alpha \cos \beta \\ -\cos \alpha \sin \beta & \cos \beta & -\sin \alpha \sin \beta \\ -\sin \alpha & 0 & \cos \alpha\end{array}\right]\left[\begin{array}{l}C_{L} \\ C_{M} \\ C_{N}\end{array}\right]$
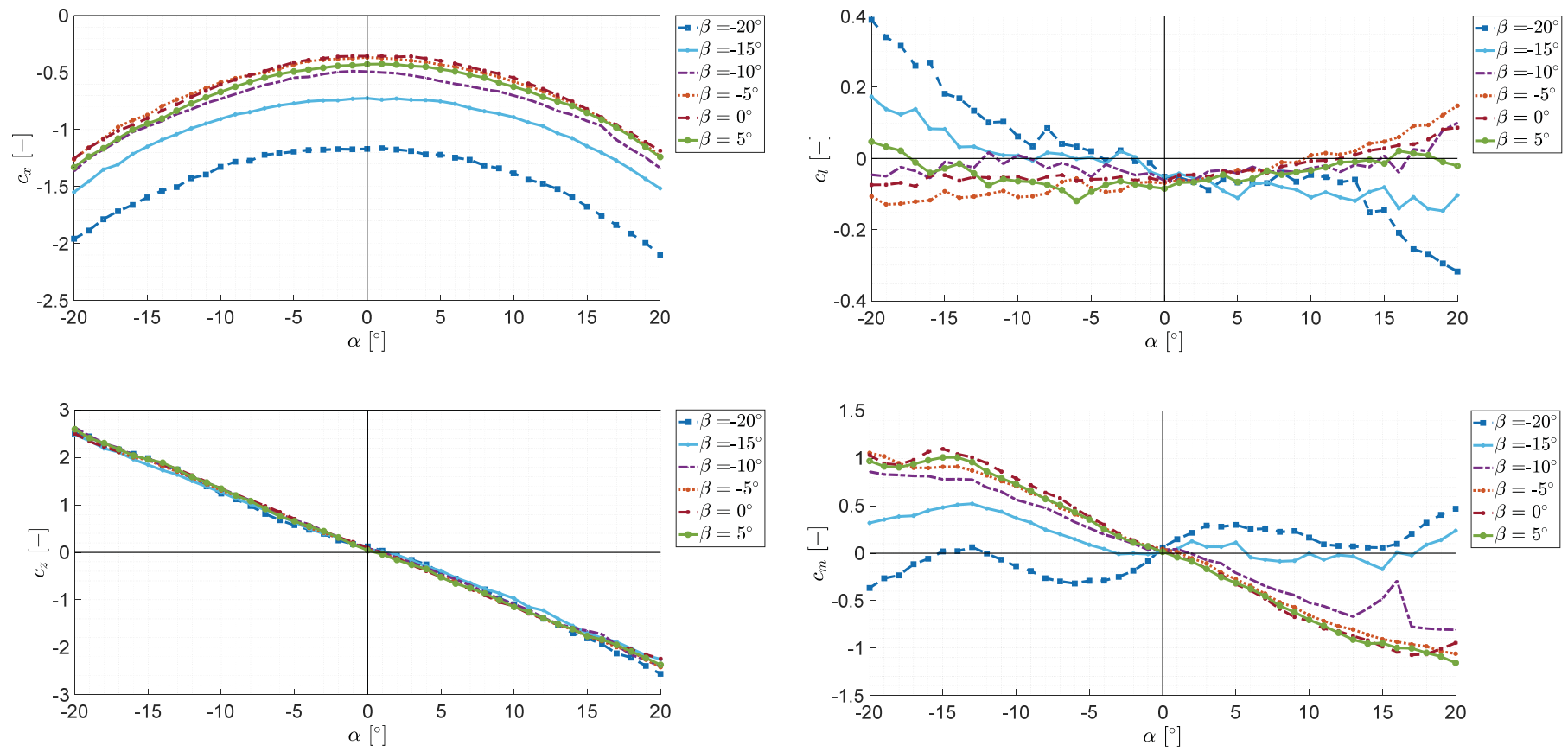

where $c_{x}, c_{y}, c_{z}$ are drag, side and lift force coefficients, respectively. Similarly, $c_{l}, c_{m}, c_{n}$ are roll, pitch and yaw moment coefficients. Some of the obtained drag force, lift force, rolling and pitching moments coefficients expressed in wind axes were presented in Fig. 10 as a function of angle of attack for various sideslip angles.

The drag coefficient presents a typical parabolic curve with the minimum of -0.35 for zero angles of attack and sideslip. The lift force characteristics are linear, coincide with each other and their slope is negative (approx. $-0.1 /^{\circ}$ ) in the whole range of $\alpha$. For $\alpha=0^{\circ}$ there is a 0.02 bias offset in the coefficient value. A small nonzero rolling moment at $\alpha=0^{\circ}$ is observed. This effect is caused by imperfections in fin mounting. With the perfect material model all the curves should cross the plot origin. The slope of pitching moment coefficient curves for $\beta=-15^{\circ},-10^{\circ},-5^{\circ}, 0^{\circ}$ and $5^{\circ}$ is negative and linear in the range $-15^{\circ} \leq \alpha \leq 15^{\circ}$, which means that the missile is statically stable at low angles of sideslip.

In a similar way the selected coefficients of drag force, side force, rolling and yawing moments for various angles of attack as a function of sideslip angle for some specific sideslip angles were presented in Fig. 11.

Drag coefficient curves have a similar, parabolic shape. The pair of lines for $\pm 5^{\circ}, \pm 10^{\circ}, \pm 15^{\circ}$ and $\pm 20^{\circ}$ nearly overlaps with each other, which is a correct result. The side force coefficient at angle of attack $\alpha=0^{\circ}$ is linear and its slope is negative. The lines crosses with the vertical axis $\alpha=0^{\circ}$ at $c_{y}=0.15$, which is quite a significant value. Moreover, for larger inflow angles some nonlinearities have appeared. The rolling moment coefficient for $\alpha=0^{\circ}$ is nearly a horizontal, straight line but again a bias error with the value -0.05 has occurred, which means a missile rolling tendency at zero inflow angles. This fact might disturb the missile roll angle immediately after exit from the launch device in the ascending, unpowered phase of flight, which will result in lateral trajectories dispersion. The yawing moment coefficient corresponds with a particular side force and for $\alpha=0^{\circ}$ the characteristic is linear with a negative slope, which means missile lateral stability. Nonlinearities occurred especially at $\alpha= \pm 20^{\circ}$ and low $\beta$, which results in instability for these regions.

Fig. 10. Aerodynamic forces and moments coefficients for various angles of sideslip

Rys. 10. Współczynniki sił i momentów aerodynamicznych dla różnych kątów ślizgu 

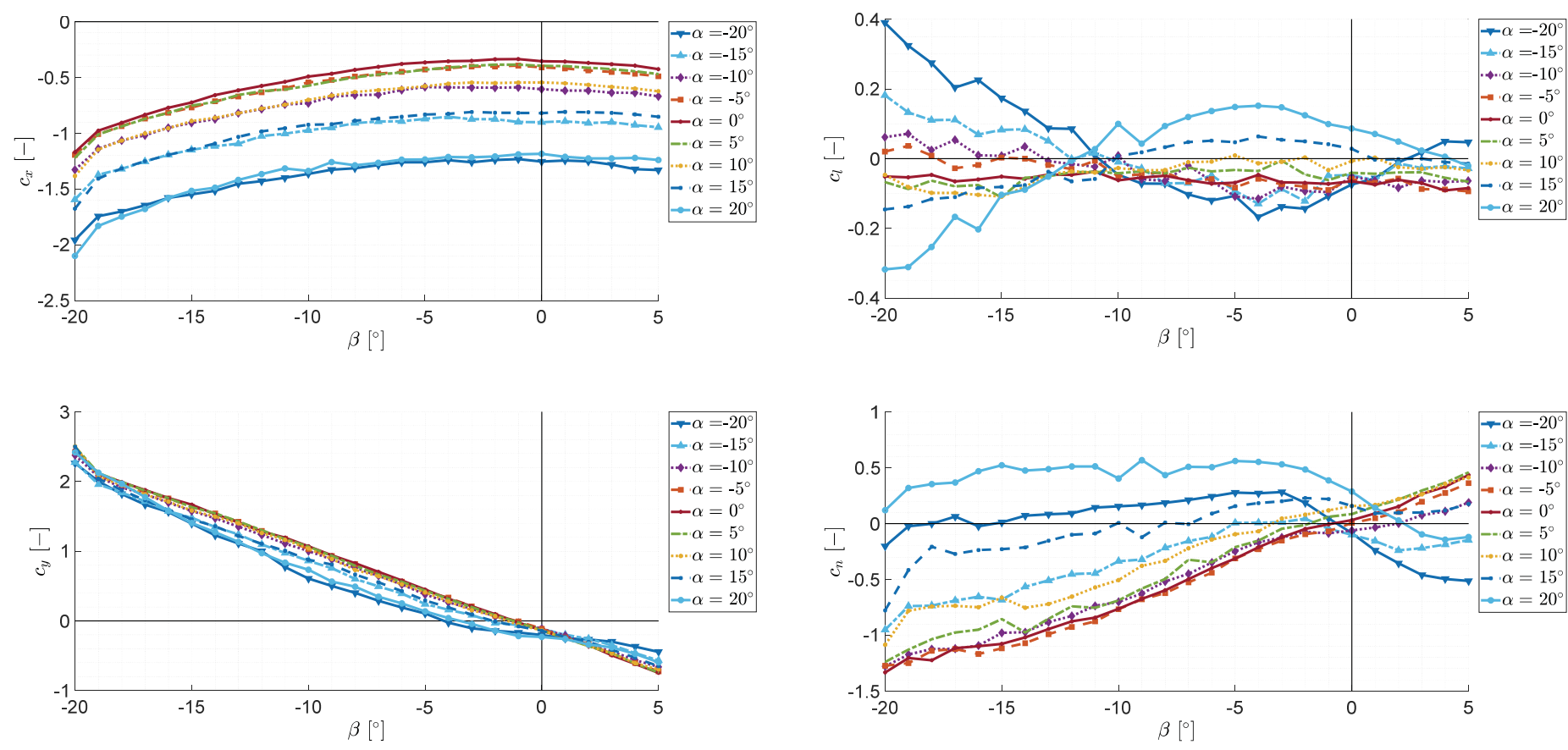

Fig. 11. Aerodynamic forces and moments coefficients for various angles of attack Rys. 11. Współczynniki sił i momentów aerodynamicznych dla różnych kątów natarcia

Selected data expressed in a wind axes coordinate system were presented in Table 1 -Table 6.
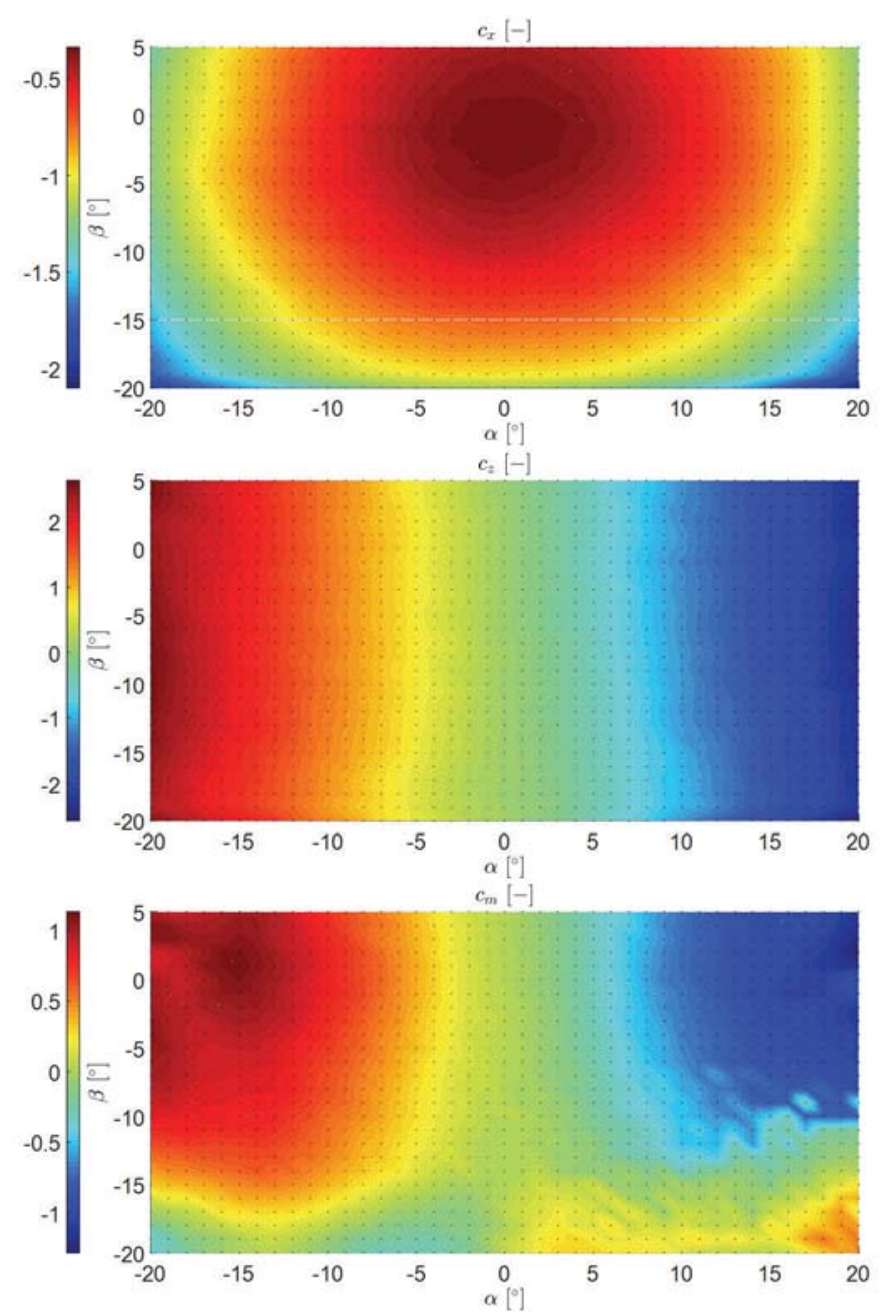

To assess the whole database space the results were visualized using contour plots (Fig. 12). The dot symbols indicate the measured points.
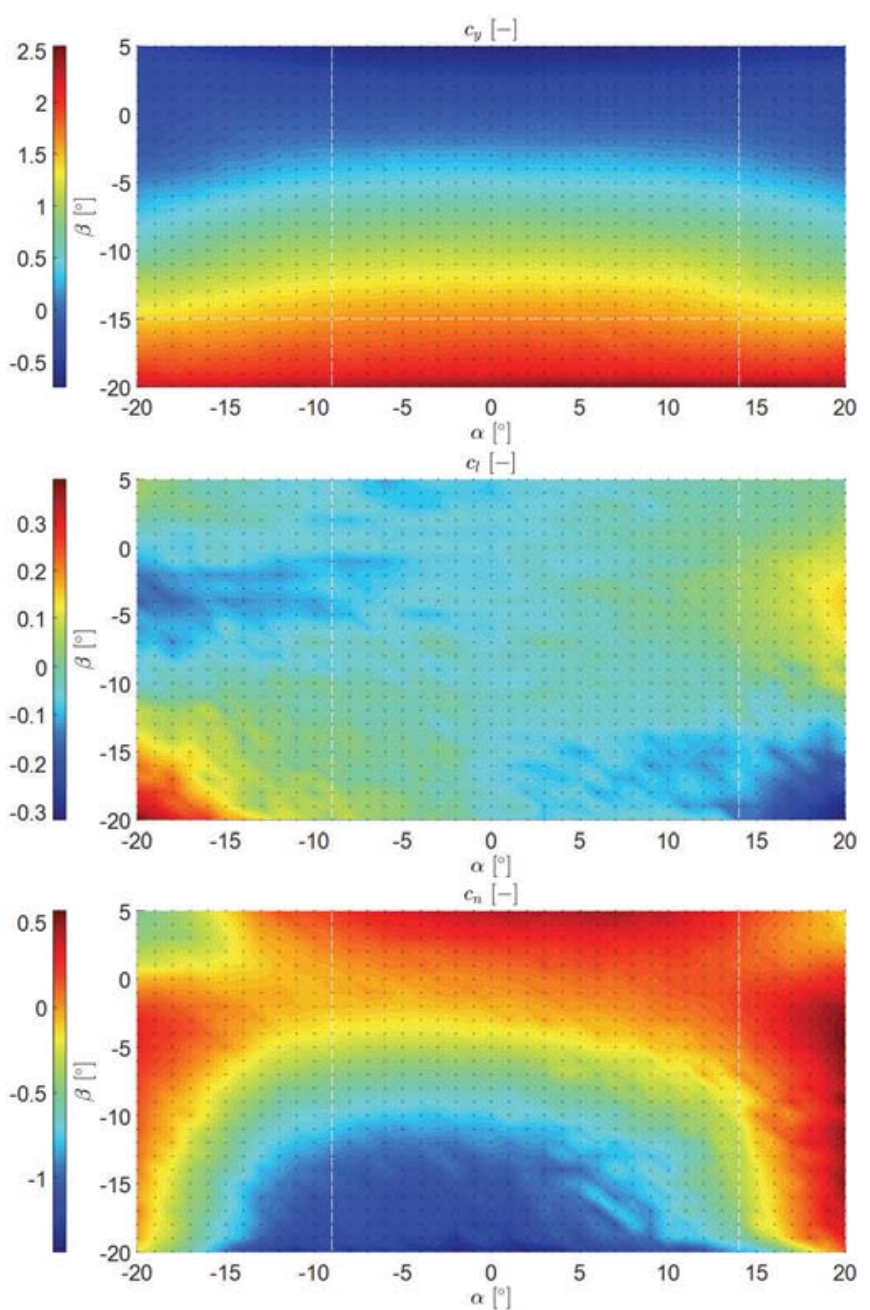

Fig. 12. Forces and moments coefficients as a function of angles of attack and sideslip Rys. 12. Współczynniki sił i momentów jako funkcja kątów natarcia i ślizgu 
Table 1. Drag force coefficients

Tabela 1. Współczynniki siły oporu

\begin{tabular}{|c|c|c|c|c|c|c|c|}
\hline$\alpha / \beta\left[^{\circ}\right]$ & -20 & -16 & -12 & -8 & -4 & 0 & 4 \\
\hline-20 & -1.9577 & -1.5791 & -1.4293 & -1.3136 & -1.2416 & -1.2542 & -1.3220 \\
\hline-16 & -1.6612 & -1.2769 & -1.1110 & -0.9793 & -0.9160 & -0.9600 & -0.9847 \\
\hline-12 & -1.4268 & -1.0363 & -0.8721 & -0.7323 & -0.6783 & -0.7142 & -0.7427 \\
\hline-8 & -1.2734 & -0.8830 & -0.7098 & -0.5795 & -0.5145 & -0.5233 & -0.5645 \\
\hline-4 & -1.1796 & -0.8087 & -0.6071 & -0.4659 & -0.3908 & -0.3882 & -0.4397 \\
\hline 0 & -1.1697 & -0.7723 & -0.5756 & -0.4318 & -0.3556 & -0.3550 & -0.3942 \\
\hline 4 & -1.2181 & -0.8108 & -0.6040 & -0.4846 & -0.3864 & -0.3764 & -0.4260 \\
\hline 8 & -1.3141 & -0.8945 & -0.6979 & -0.5726 & -0.4901 & -0.4827 & -0.5287 \\
\hline 12 & -1.4744 & -1.0295 & -0.8553 & -0.7196 & -0.6456 & -0.6425 & -0.6760 \\
\hline 16 & -1.7549 & -1.2565 & -1.0669 & -0.9615 & -0.8933 & -0.8916 & -0.8906 \\
\hline 20 & -2.1002 & -1.5795 & -1.3669 & -1.2873 & -1.2133 & -1.1852 & -1.2208 \\
\hline
\end{tabular}

Table 2. Side force coefficients

Tabela 2. Współczynniki siły bocznej

\begin{tabular}{|c|c|c|c|c|c|c|c|}
\hline$\alpha / \beta\left[^{\circ}\right]$ & -20 & -16 & -12 & -8 & -4 & 0 & 4 \\
\hline-20 & 2.2609 & 1.5614 & 1.0004 & 0.4021 & -0.0258 & -0.2011 & -0.3682 \\
\hline-16 & 2.2631 & 1.5907 & 1.0926 & 0.5780 & 0.0963 & -0.1299 & -0.4493 \\
\hline-12 & 2.3577 & 1.6489 & 1.2031 & 0.7213 & 0.2261 & -0.1053 & -0.5236 \\
\hline-8 & 2.3941 & 1.7102 & 1.2597 & 0.7720 & 0.2989 & -0.1045 & -0.5659 \\
\hline-4 & 2.4297 & 1.7502 & 1.2999 & 0.8254 & 0.3193 & -0.1187 & -0.5968 \\
\hline 0 & 2.4574 & 1.7618 & 1.2815 & 0.8275 & 0.3165 & -0.1356 & -0.6178 \\
\hline 4 & 2.5373 & 1.7666 & 1.2947 & 0.8140 & 0.3084 & -0.1203 & -0.6062 \\
\hline 8 & 2.5149 & 1.7477 & 1.2631 & 0.7953 & 0.3017 & -0.1362 & -0.5933 \\
\hline 12 & 2.4827 & 1.6872 & 1.2385 & 0.7305 & 0.2555 & -0.1370 & -0.5723 \\
\hline 16 & 2.4970 & 1.5823 & 1.0914 & 0.6293 & 0.1635 & -0.1572 & -0.5125 \\
\hline 20 & 2.4172 & 1.5794 & 0.9713 & 0.4906 & 0.0407 & -0.2303 & -0.4732 \\
\hline
\end{tabular}

Table 3 Lift force coefficients

Tabela 3 Współczynniki siły nośnej

\begin{tabular}{|c|c|c|c|c|c|c|c|}
\hline$\alpha / \beta\left[^{\circ}\right]$ & -20 & -16 & -12 & -8 & -4 & 0 & 4 \\
\hline-20 & 2.4996 & 2.4199 & 2.5620 & 2.6031 & 2.5397 & 2.4989 & 2.5922 \\
\hline-16 & 2.0724 & 1.9725 & 2.0513 & 2.0558 & 2.0198 & 2.0580 & 2.0424 \\
\hline-12 & 1.5508 & 1.4762 & 1.5831 & 1.5297 & 1.5697 & 1.6223 & 1.5814 \\
\hline-8 & 0.9784 & 0.9503 & 1.0691 & 1.0640 & 1.0761 & 1.0998 & 1.0808 \\
\hline-4 & 0.4752 & 0.4816 & 0.5357 & 0.5535 & 0.5737 & 0.5719 & 0.5210 \\
\hline 0 & 0.1258 & 0.0881 & 0.1012 & 0.1414 & 0.0944 & 0.0931 & 0.0546 \\
\hline 4 & -0.2539 & -0.2509 & -0.3392 & -0.3562 & -0.3934 & -0.3909 & -0.3983 \\
\hline 8 & -0.7837 & -0.7727 & -0.8121 & -0.8370 & -0.8819 & -0.9055 & -0.8821 \\
\hline 12 & -1.3973 & -1.2198 & -1.3527 & -1.3622 & -1.3748 & -1.4029 & -1.4007 \\
\hline 16 & -1.9321 & -1.7594 & -1.8126 & -1.8866 & -1.8797 & -1.8630 & -1.8500 \\
\hline 20 & -2.5604 & -2.2476 & -2.2943 & -2.4283 & -2.3736 & -2.2421 & -2.3409 \\
\hline
\end{tabular}


Table 4. Rolling moment coefficients

Tabela 4. Współczynniki momentu przechylającego

\begin{tabular}{|c|c|c|c|c|c|c|c|}
\hline$\alpha / \beta\left[^{\circ}\right]$ & -20 & -16 & -12 & -8 & -4 & 0 & 4 \\
\hline-20 & 0.3896 & 0.2254 & 0.0856 & -0.0716 & -0.1673 & -0.0743 & 0.0496 \\
\hline-16 & 0.2692 & 0.1238 & 0.0886 & -0.0526 & -0.1130 & -0.0486 & -0.0300 \\
\hline-12 & 0.1010 & 0.0246 & 0.0107 & -0.0852 & -0.1196 & -0.0540 & -0.0628 \\
\hline-8 & 0.0849 & 0.0003 & -0.0147 & -0.0529 & -0.0828 & -0.0512 & -0.0578 \\
\hline-4 & -0.0056 & 0.0087 & -0.0314 & -0.0527 & -0.0511 & -0.0578 & -0.0933 \\
\hline 0 & -0.0513 & -0.0595 & -0.0466 & -0.0491 & -0.0466 & -0.0648 & -0.0912 \\
\hline 4 & -0.0593 & -0.0736 & -0.0595 & -0.0393 & -0.0483 & -0.0361 & -0.0664 \\
\hline 8 & -0.0400 & -0.0814 & -0.0426 & -0.0271 & 0.0005 & -0.0225 & -0.0454 \\
\hline 12 & -0.0668 & -0.1237 & -0.0416 & -0.0219 & 0.0243 & -0.0005 & -0.0264 \\
\hline 16 & -0.2089 & -0.1052 & -0.0286 & 0.0272 & 0.0729 & 0.0372 & -0.0161 \\
\hline 20 & -0.3176 & -0.2029 & -0.0058 & 0.0936 & 0.1520 & 0.0866 & 0.0056 \\
\hline
\end{tabular}

Table 5. Pitching force coefficients

Tabela 5. Współczynniki momentu pochylającego

\begin{tabular}{|c|c|c|c|c|c|c|c|}
\hline$\alpha / \beta\left[^{\circ}\right]$ & -20 & -16 & -12 & -8 & -4 & 0 & 4 \\
\hline-20 & -0.3664 & 0.1285 & 0.6599 & 0.9613 & 1.0791 & 1.0336 & 1.0873 \\
\hline-16 & -0.0581 & 0.3229 & 0.6779 & 0.8538 & 0.9290 & 1.0677 & 1.0108 \\
\hline-12 & -0.0032 & 0.3761 & 0.6265 & 0.7872 & 0.8602 & 0.9483 & 0.9311 \\
\hline-8 & -0.2631 & 0.1562 & 0.3840 & 0.4851 & 0.5824 & 0.6379 & 0.5853 \\
\hline-4 & -0.2888 & -0.0401 & 0.1642 & 0.2165 & 0.2700 & 0.3002 & 0.2732 \\
\hline 0 & 0.0612 & 0.0220 & 0.0389 & 0.0310 & 0.0309 & 0.0205 & 0.0166 \\
\hline 4 & 0.2797 & 0.1315 & -0.1033 & -0.1743 & -0.2051 & -0.2251 & -0.2313 \\
\hline 8 & 0.2250 & -0.0730 & -0.3229 & -0.4688 & -0.5300 & -0.5867 & -0.5405 \\
\hline 12 & 0.0773 & 0.0320 & -0.5494 & -0.6886 & -0.7643 & -0.8221 & -0.8188 \\
\hline 16 & 0.0982 & 0.0195 & -0.4246 & -0.8332 & -0.9318 & -1.0370 & -0.9700 \\
\hline 20 & 0.4688 & 0.3783 & -0.1233 & -0.9376 & -1.0597 & -0.9449 & -1.1938 \\
\hline
\end{tabular}

Table 6. Yawing force coefficients

Tabela 6. Współczynniki momentu odchylającego

\begin{tabular}{|c|c|c|c|c|c|c|c|}
\hline$\alpha / \beta\left[^{\circ}\right]$ & -20 & -16 & -12 & -8 & -4 & 0 & 4 \\
\hline-20 & -0.2028 & -0.0244 & 0.0913 & 0.1862 & 0.2716 & -0.0851 & -0.4960 \\
\hline-16 & -0.7635 & -0.4904 & -0.4102 & -0.1583 & 0.0927 & -0.1027 & -0.2808 \\
\hline-12 & -1.2948 & -0.9599 & -0.7443 & -0.4794 & -0.1312 & -0.0742 & 0.0426 \\
\hline-8 & -1.3242 & -1.0927 & -0.9071 & -0.5731 & -0.2160 & -0.0279 & 0.1859 \\
\hline-4 & -1.3477 & -1.1354 & -0.9298 & -0.6136 & -0.2245 & -0.0040 & 0.2828 \\
\hline 0 & -1.3337 & -1.0984 & -0.8767 & -0.5969 & -0.2115 & 0.0307 & 0.3309 \\
\hline 4 & -1.3842 & -0.9824 & -0.8459 & -0.5119 & -0.1598 & 0.0709 & 0.3591 \\
\hline 8 & -1.2146 & -0.8714 & -0.7253 & -0.4349 & -0.0879 & 0.1341 & 0.3628 \\
\hline 12 & -1.0733 & -0.5834 & -0.5320 & -0.2575 & 0.0271 & 0.1291 & 0.2759 \\
\hline 16 & -0.6418 & -0.1358 & -0.0589 & 0.0362 & 0.2746 & 0.1668 & 0.0810 \\
\hline 20 & 0.1192 & 0.4686 & 0.5123 & 0.4348 & 0.5525 & 0.2879 & -0.1449 \\
\hline
\end{tabular}


The smallest absolute value of drag has occurred at zero inflow angles and the plot has a circular symmetry, which is typical for objects with an axisymmetric body. The contour maps for side force and lift force coefficients have a mirror symmetry with respect to vertical and horizontal lines corresponding with $\alpha=0^{\circ}$ and $\beta=0^{\circ}$. In the rolling moment coefficient plot there are some small irregular regions. The pitching moment coefficient is not perfectly symmetric with respect to $\alpha=0^{\circ}$ for $\beta<-12^{\circ}$.

Next, the results were implemented into two-dimensional lookup tables and used in the 6DoF numerical flight simulation.

\section{Monte-Carlo Missile Flight Simulations}

A set of Monte-Carlo flight simulations [13] was evaluated to investigate the full-scale missile behavior using the aerodynamic database which was developed using wind tunnel tests methodology.

The main goal of the numerical experiments was to assess the repeatability of the cold launch maneuver under various external disturbances. The minimal number of thrusters which allows controlled, rapid orientation change is equal to two $[2,5]$. Two lateral thrusters placed before the missile center of mass, $1.3 \mathrm{~m}$ from the base at the opposite sides of the fuselage were used to perform the cold launch maneuver. In this configuration the missile is uncontrolled in the roll channel. Most of the existing cold launch missiles are roll stabilized.

The mathematical model of the missile described in [5, 14] was used and implemented into MATLAB 2018a software. Flat Earth approximation was used for the simulation. Air thermodynamic properties were assumed according to [15]. The missile was modeled as a variable mass rigid body with six degrees of freedom. The center of mass location shift due to main motor grain burnout was included in the model. The full-scale missile maximum velocity was predicted to be approximately $90 \mathrm{~m} / \mathrm{s}$, so for such a subsonic range it was assumed that the coefficients variation with speed is negligible. The wind influence on the missile trajectory was neglected.

The equations of motion of the missile were as follows $[5,16]$ :

$$
\left[\begin{array}{c}
\dot{U} \\
\dot{V} \\
\dot{W}
\end{array}\right]=\frac{1}{m}\left[\begin{array}{c}
X_{b} \\
Y_{b} \\
Z_{b}
\end{array}\right]-\left[\begin{array}{ccc}
0 & -R & Q \\
R & 0 & -P \\
-Q & P & 0
\end{array}\right]\left[\begin{array}{c}
U \\
V \\
W
\end{array}\right]
$$

$$
\left[\begin{array}{c}
\dot{P} \\
\dot{Q} \\
\dot{R}
\end{array}\right]=\mathbf{I}^{-1}\left[\begin{array}{c}
L_{b} \\
M_{b} \\
N_{b}
\end{array}\right]-\mathbf{I}^{-1}\left[\begin{array}{ccc}
0 & -R & Q \\
R & 0 & -P \\
-Q & P & 0
\end{array}\right] \mathbf{I}\left[\begin{array}{c}
P \\
Q \\
R
\end{array}\right]
$$

$$
\left[\begin{array}{c}
\dot{\Phi} \\
\dot{\Theta} \\
\dot{\Psi}
\end{array}\right]=\left[\begin{array}{ccc}
1 & \sin \Phi \tan \Theta & \cos \Phi \tan \Theta \\
0 & \cos \Phi & -\sin \Phi \\
0 & \sin \Phi / \cos \Theta & \cos \Phi / \cos \Theta
\end{array}\right]\left[\begin{array}{c}
P \\
Q \\
R
\end{array}\right]
$$

where $U_{0}, V_{0}, W_{0}$ are missile linear velocities in the body axis frame, $P_{0}, Q_{0}, R_{0}$ are missile roll rates, $\Phi_{0}, \Theta_{0}, \Psi_{0}$ are initial Euler angles (roll, pitch and yaw), $x_{n}, y_{n}, z_{n}$ are initial position coordinates of the missile center of mass. The dot symbol above some variables denotes a derivative with respect to time. is projectile mass and $\boldsymbol{I}$ is the inertia matrix in the form

$$
\mathbf{I}=\left[\begin{array}{ccc}
I_{x} & 0 & 0 \\
0 & I_{y} & 0 \\
0 & 0 & I_{z}
\end{array}\right]
$$

Forces $\boldsymbol{F}_{b}$ and moments $\boldsymbol{M}_{b}$ which act on the missile were calculated as [16]

$$
\boldsymbol{F}_{b}=\left[\begin{array}{c}
X_{b} \\
Y_{b} \\
Z_{b}
\end{array}\right]=\boldsymbol{F}_{g}+\boldsymbol{F}_{s}+\boldsymbol{F}_{a}+\boldsymbol{F}_{c}
$$

where $\boldsymbol{F}_{q}$ are gravity, $\boldsymbol{F}_{s}$ propulsive, $\boldsymbol{F}_{a}$ aerodynamic and $\boldsymbol{F}_{c}$ control forces generated by lateral thrusters. Similarly

$$
\boldsymbol{M}_{b}=\left[\begin{array}{c}
L_{b} \\
M_{b} \\
N_{b}
\end{array}\right]=M_{g}+M_{s}+M_{a}+M_{c}
$$

are the corresponding moments.

The gravity loads $\boldsymbol{F}_{q}$ and $\boldsymbol{M}_{q}$ in the body coordinate system $O_{b} x_{b} y_{b} z_{b}$ were calculated according to $[5,17]$. The main motor thrust axis misalignment was included in the model. The propulsive forces are [17]

$$
\boldsymbol{F}_{s}=\left[\begin{array}{c}
X_{s} \\
Y_{s} \\
Z_{s}
\end{array}\right]=T(t)\left[\begin{array}{c}
\cos \Psi_{\mathrm{T}} \cos \Theta_{\mathrm{T}} \\
\cos \Theta_{\mathrm{T}} \sin \Psi_{\mathrm{T}} \\
-\sin \Theta_{\mathrm{T}}
\end{array}\right]
$$

$$
\left[\begin{array}{c}
\dot{x}_{n} \\
\dot{y}_{n} \\
\dot{z}_{n}
\end{array}\right]=\left[\begin{array}{ccc}
\cos \Theta \cos \Psi & \sin \Phi \sin \Theta \cos \Psi-\cos \Phi \sin \Psi & \cos \Phi \sin \Theta \cos \Psi+\sin \Phi \sin \Psi \\
\cos \Theta \sin \Psi & \sin \Phi \sin \Theta \sin \Psi+\cos \Phi \cos \Psi & \cos \Phi \sin \Theta \sin \Psi-\sin \Phi \cos \Psi \\
-\sin \Theta & \sin \Phi \cos \Theta & \cos \Phi \cos \Theta
\end{array}\right]\left[\begin{array}{c}
U \\
V \\
W
\end{array}\right]
$$


and the moments

$$
\boldsymbol{M}_{s}=\left[\begin{array}{c}
L_{s} \\
M_{s} \\
N_{s}
\end{array}\right]=T(t)\left[\begin{array}{c}
0 \\
-l_{n} \sin \Theta_{\mathrm{T}} \\
-\cos \Theta_{\mathrm{T}} \sin \Psi_{\mathrm{T}}
\end{array}\right]
$$

where $T(t)$ is the main motor thrust, $\Theta_{\mathrm{T}}$ and $\Psi_{\mathrm{T}}$ are thrust pitch and yaw misalignment angles; $l_{n}$ is the distance from the center of mass to the main motor nozzle exit plane. The center of mass location from the base before and after main motor burnout was $0.66 / 0.7 \mathrm{~m}$.

The aerodynamic forces which act on the projectile are

$$
\boldsymbol{X}_{a}=\frac{1}{2} \rho V_{0}^{2} S\left[\begin{array}{c}
C_{X}\left(\alpha, \beta, E_{\text {state }}\right) \\
C_{Y}(\alpha, \beta) \\
C_{Z}(\alpha, \beta)
\end{array}\right]
$$

and the aerodynamic moments are described by

$$
M_{a}=\frac{1}{2} \rho V_{0}^{2} S d\left[\begin{array}{c}
C_{L}(\alpha, \beta)+C_{L P}(\alpha, \beta) \frac{P d}{2 V_{0}} \\
C_{M}(\alpha, \beta)+C_{M Q}(\alpha, \beta) \frac{Q d}{2 V_{0}} \\
C_{N}(\alpha, \beta)+C_{N R}(\alpha, \beta) \frac{R d}{2 V_{0}}
\end{array}\right]
$$

where $\rho$ is air density, $V_{0}$ is total aerodynamic velocity, $S=\omega d^{2} / 4$ is the projectile cross section area, $d$ is the missile diameter, $\alpha$ is angle of attack, $\beta$ - angle of sideslip. $C_{X}, C_{Y}, C_{Z}$ are axial, side and normal force nondimensional coefficients. $C_{L}$ is spin driving moment coefficient due to fin mounting misalignments, and $C_{L P}, C_{M Q}, C_{N R}$ are roll, pitch and yaw damping moment coefficients, which were estimated using the method described in [18]. $E_{\text {state }}$ is the main motor state $(0$ - powered flight, 1 unpowered). Aerodynamic coefficients were implemented into the software using the lookup table method. Due the high cost of modernization of the laboratory stand in order to measure the damping moment coefficients they were obtained using semi-empirical methods presented in [19].

The lateral thruster loads were computed as:

$$
\boldsymbol{X}_{c}=\sum_{i}^{n} T\left[\begin{array}{c}
0 \\
\sin \Phi_{i} \\
-\cos \Phi_{i}
\end{array}\right]
$$

and

$$
\boldsymbol{M}_{c}=\sum_{i}^{n} l_{l t} T\left[\begin{array}{c}
0 \\
\sin \Phi_{i} \\
-\cos \Phi_{i}
\end{array}\right]
$$

where $l_{l t}$ is the distance between the center of mass and lateral thruster nozzle projected on the longitudinal axis of the missile and $\Phi_{i}$ is the angular location of the thruster. The operation

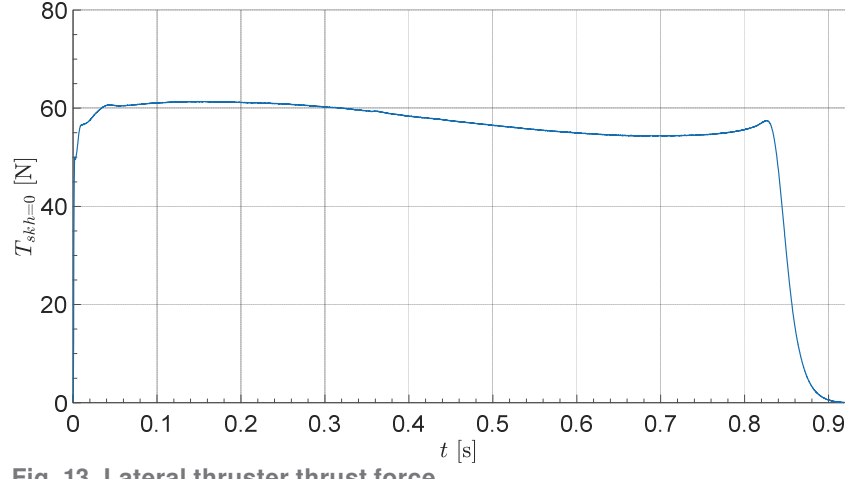

Fig. 13. Lateral thruster thrust force

Rys. 13. Ciąg silnika korekcyjnego

time of the thrusters was set to $0.9 \mathrm{~s}$ and the thrust force amplitude to approximately $60 \mathrm{~N}$ (Fig. 13).

The first and second thruster were initialized in $0.95 \mathrm{~s}$ and $1 \mathrm{~s}$ of flight, respectively. The main motor missile was fired with $0.4 \mathrm{~s}$ time delay after second thruster firing. Each of the indi-

\begin{tabular}{|c|c|c|c|c|}
\hline no. & parameter & mean value & $\begin{array}{l}\text { standard } \\
\text { deviation }\end{array}$ & unit \\
\hline 1 & $m_{0}$ & 15.67 & 0.05 & $\mathrm{~kg}$ \\
\hline 2 & $m_{k}$ & 14.94 & 0.05 & $\mathrm{~kg}$ \\
\hline 3 & $I_{x 0}$ & 0.057 & 0.01 & $\mathrm{kgm}^{2}$ \\
\hline 4 & $I_{x k}$ & 0.056 & 0.01 & $\mathrm{kgm}^{2}$ \\
\hline 4 & $I_{y k}$ & 3.6 & 0.01 & $\mathrm{kgm}^{2}$ \\
\hline 4 & $I_{y k}$ & 3.45 & 0.01 & $\mathrm{kgm}^{2}$ \\
\hline 5 & $U_{0}$ & 17 & 1 & $\mathrm{~m} / \mathrm{s}$ \\
\hline 6 & $V_{0}$ & 0 & 0.1 & $\mathrm{~m} / \mathrm{s}$ \\
\hline 7 & $W_{0}$ & 0 & 0.1 & $\mathrm{~m} / \mathrm{s}$ \\
\hline 8 & $P_{0}$ & 0 & 10 & $\% / \mathrm{s}$ \\
\hline 9 & $Q_{0}$ & 0 & 1 & $\% / \mathrm{s}$ \\
\hline 10 & $R_{0}$ & 0 & 1 & $\% / \mathrm{s}$ \\
\hline 11 & $\Phi_{0}$ & 0 & 0.2 & $\circ$ \\
\hline 12 & $\Theta_{0}$ & 90 & 0.1 & $\circ$ \\
\hline 13 & $\Psi_{0}$ & 0 & 0.1 & $\circ$ \\
\hline 14 & $x_{n}$ & 0 & 0.02 & $\mathrm{~m}$ \\
\hline 15 & $y_{n}$ & 0 & 0.02 & $\mathrm{~m}$ \\
\hline 16 & $z_{n}$ & 0 & 0.02 & $\mathrm{~m}$ \\
\hline 17 & $\Theta_{\mathrm{T}}$ & 0 & 0.01 & 。 \\
\hline 18 & $\Psi_{\mathrm{T}}$ & 0 & 0.01 & $\circ$ \\
\hline
\end{tabular}
vidual disturbances was modelled as Gauss distribution. The simulation initial conditions are presented in Table 7.

Table 7. Monte-Carlo simulation initial conditions

Tabela 7. Warunki początkowe dla symulacji Monte-Carlo

$m_{0}, m_{k}-$ missile mass, $I_{x 0} / I_{x k}-$ longitudinal, $I_{y 0} / I_{y k}$ and $I_{z 0} / I_{z k}$ - lateral moments of inertia before/after main motor firing. The Marsenne-Twister algorithm was used to generate pseu- 


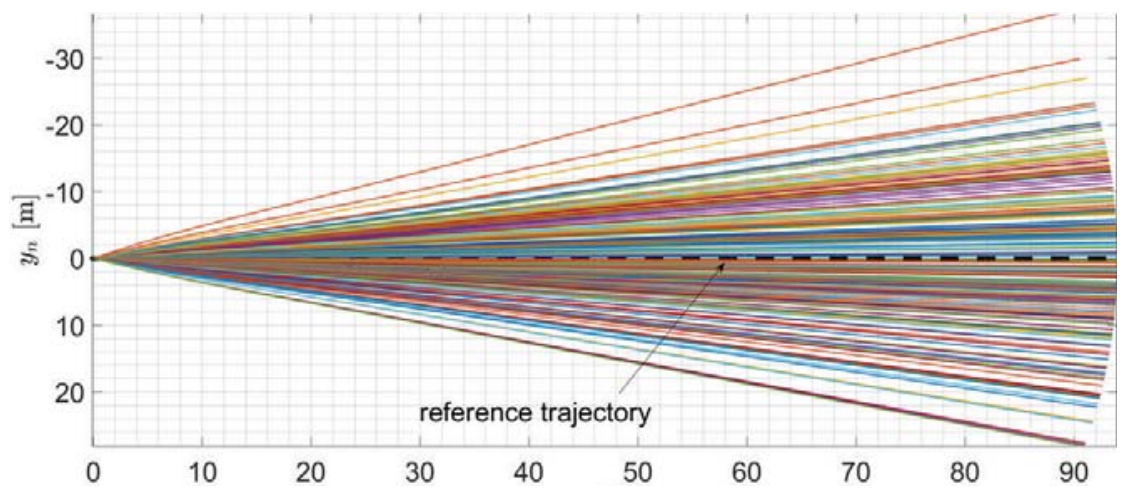

$x_{n}[\mathrm{~m}]$
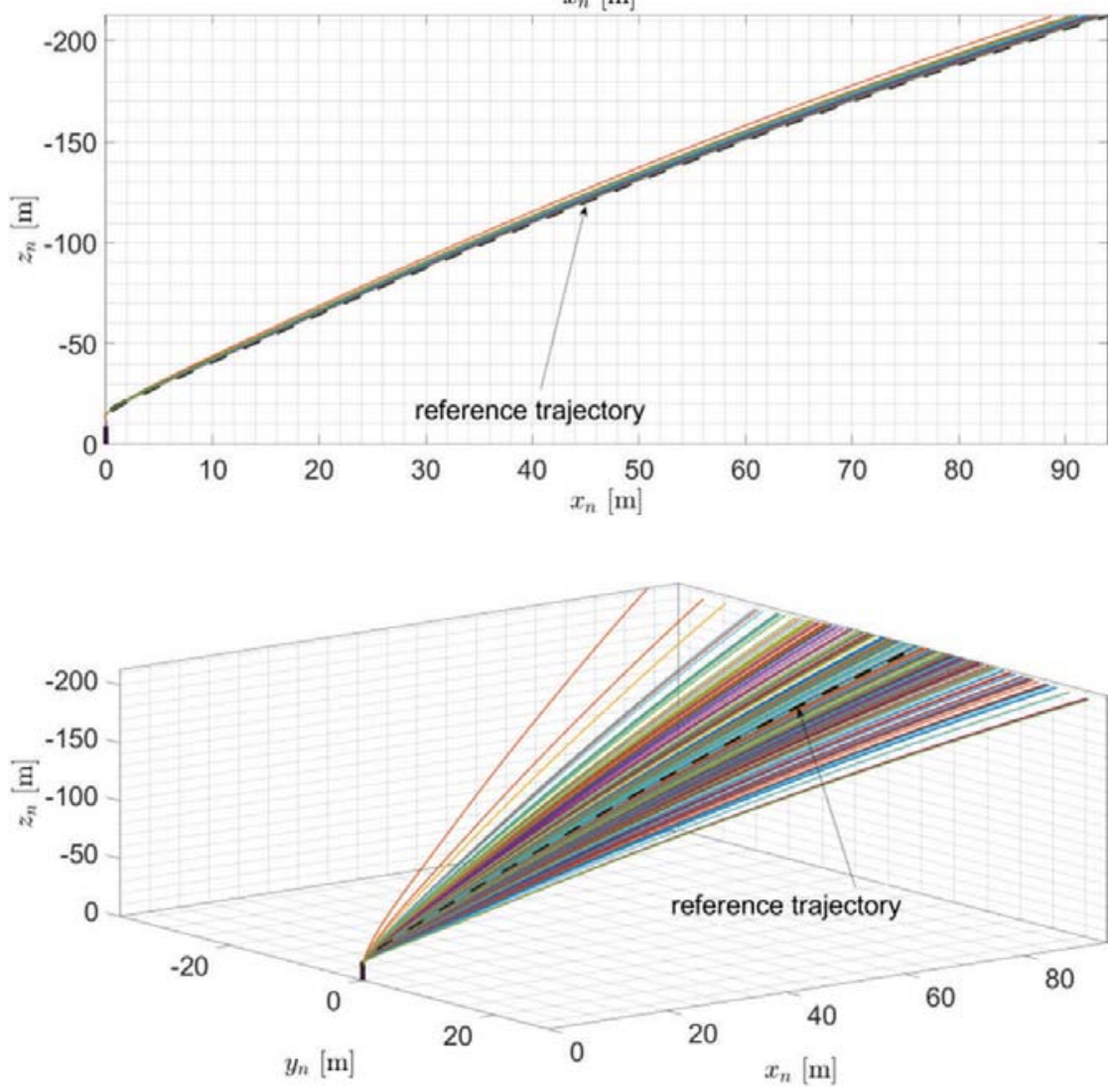

Fig. 14. Missile trajectories visualisation

Rys. 14. Wizualizacja trajektorii rakiety

dorandom numbers. 200 numerical simulations were performed using Simulink rapid accelerator mode on a desktop PC with i7-4790 CPU @3.60 GHz and 16 GB DDR3 RAM. The flight duration for each case was set to $5 \mathrm{~s}$. Figure 14 shows initial portions of the missile trajectories.

The missile altitude change maneuver takes place when the object is at the attitude of $17 \mathrm{~m}$. The black, dotted line means a reference trajectory for zero standard deviations each from the parameters. For nonexistent error sources, all the trajectories should be the same and coincide with this line. Strong lateral dispersion on the left and right from the $O_{n} x_{n} z_{n}$ plane is observable. The lateral dispersion at the end of the flight was from -91 to 88.7. The differences in elevation are smaller but also not negligible. The simulations proved that the full-scale missile is statically stable. The dispersion of trajectories is mainly the result of nonzero initial missile roll rate $P_{0}$ about its longitudinal axis. It proves that the used methodology of wind tunnel measurements could be used successfully for numerical flight dynamic simulation purposes.

\section{Conclusion}

This paper presents the results of subsonic wind tunnel testing of a model missile intended for the vertical cold launch system. The static aerodynamic characteristics were acquired successfully as a function of angles of attack and sideslip with the internal six component balance. The aerodynamic database obtained during wind tests was used in the Monte-Carlo simulations of the missile trajectories. Due to lack of roll stabilization a significant dispersion has been observed. It was concluded that the fin mounting must be checked carefully to eliminate possible rolling moment due to nonzero fin cant angles. Oscillations of the test object might occur at high angles of attack, which results in limited quality of some coefficients. During wind tunnel tests it was observed that the main problem was connected with testing objects with small lifting surfaces like missile fins, so it is necessary to have high accuracy aerodynamic balance, which determines the quality of the results. For further work, oil, tufts or pressure sensitive 
paint visualization should be performed to study the flow field around the missile body in detail.

\section{References}

1. Titchener P.E., Veitch A.J., UK Soft Vertical Launch A Flexible Solution to an Integral Concept for Ground $\&$ Naval Air Defence, [in:] RTO MP-063, 2000.

2. Taur D.-R., Chern J.-S., Optimal Side Jet Control for Vertically Cold Launched Tactical Missiles, [in:] XIAA Guidance, Navigation, and Control Conference and Exhibit, Denver, 2000, DOI: $10.2514 / 6.2000-4164$.

3. Ocokoljić G., Rašuo B., Testing an Anti Tank Missile Model with Jet Simulation in the T-35 Subsonic Wind Tunnel, "Scientific Technical Review", Vol. 62, No. 3-4, 2012, 14-20.

4. Ocokoljić G., Rašuo B., Aerodynamic testing model guided missiles with jets simulations in the T-35 wind tunnel, 2014, 629-634, DOI: 10.5937/tehnika1404629O.

5. Jacewicz M., Głębocki R., Simulation study of a missile cold launch system, "Journal of Theoretical and Applied Mechanics", Vol. 56, No. 4, 2018, 901-913, DOI: 10.15632/jtam-pl.56.4.901.

6. Barlow J.B., Rae W.H., Pope A., Low-Speed Wind Tunnel Testing, New York: John Wiley \& Sons, Inc., 1999.

7. Rosema C., Doyle J., Blake W., Missile Data Compendium (DATCOM) - User Manual - 2014 Revision, 2014.

8. Moore F., Hymer T., The 2002 Version of the Aeroprediction Code: Part I - Summary of New Theoretical Methodology, Naval Surface Warfare Center, 2002.

9. Smędra K., Świerkot R., Kubryński K., Low speed wind tunnel test of the jet trainer model at high angles of attack, "Journal of KONES Powertrain and Transport", Vol. 23, No. 4, 2016, 471-478, DOI: 10.5604/12314005.1217285.
10. Allerton D., Principles of Flight Simulation, Wiltshire: John Wiley \& Sons, 2009.

11. Ładyżyńska-Kozdraś E., Filipowicz M., Maryniak J., Modelowanie dynamiki oraz identyfikacja aerodynamiczna zmodyfikowanego pocisku moździerzowego kalibru 74 mm, „Problemy mechatroniki. Uzbrojenie, lotnictwo, inżynieria bezpieczeństwa", Vol. 2, No. 8, 2012, 51-62.

12. Advisory Group For Aerospace Research \& Development, AGARDograph 336 Wind tunnel wall correction, North Atlantic Treaty Organization, 1998.

13. Ilg M., Rogers J., Costello M., Projectile Monte-Carlo Trajectory Analysis Using a Graphics Processing Unit, [in:] AIAA Atmospheric Flight Mechanics Conference, Portland, 2011, DOI: 10.2514/6.2011-6266.

14. Głębocki R., Jacewicz M., Missile Vertical Launch System with Reaction Control Jets, Vol. 145, No. 1, 2018, 25-46, DOI: 10.5604/01.3001.0012.1271.

15. National Aeronautics and Space Administration, U.S. Standard Atmosphere, Washington, D.C., 1976.

16. Jitpraphai T., Costello M., Dispersion Reduction of a Direct Fire Rocket Using Lateral Pulse Jets, "Journal of Spacecraft and Rockets", Vol. 38, No. 6, 2001, 929-936, DOI: $10.2514 / 2.3765$.

17. Department of Defense, Military Handbook. Missile Flight Simulation. Part One - Surface to Air missiles, Department of Defense, 17 July 1995.

18. Danberg J., Weinacht P., An Approximate Method for Pitch-Damping Prediction, Aberdeen Proving Ground: Army Research Laboratory, 2003.

19. STANAG 4655 - An Engineering Model To Estimate Aerodynamic Coefficient, NATO Standardization Agency, Bruxelles 2014.

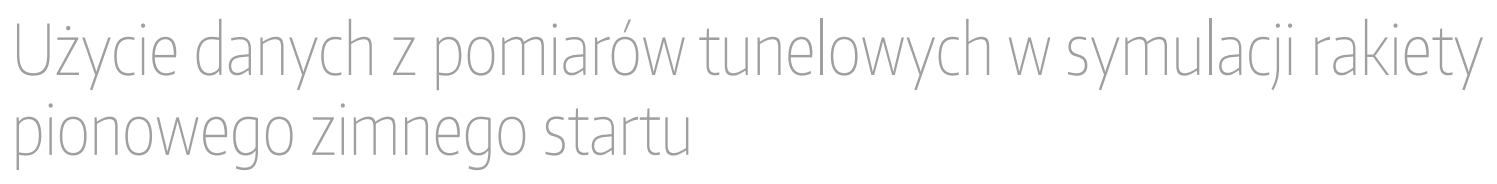

\author{
Streszczenie: Niniejszy artykuł przedstawia wyniki testów w tunelu aerodynamicznym modelu \\ rakiety dedykowanej dla pionowego zimnego startu. Celem pracy było uzyskanie bezwymiarowych \\ współczynników aerodynamicznych potrzebnych do opracowania bazy w postaci tablic dla \\ numerycznej symulacji lotu o sześciu stopniach swobody. Model materialny pełnowymiarowej rakiety \\ został zaprojektowany przy wykorzystaniu programu Siemens UG/NX. Testy zostały przeprowadzone \\ na Politechnice Warszawskiej przy niskiej prędkości przepływu a charakterystyki statycznych sił \\ i momentów uzyskano za pomocą sześcioskładnikowej wagi wewnętrznej dla szerokiego zakresu \\ kątów natarcia i ślizgu z krokiem $1^{\circ}$. Ostatecznie, przeprowadzono 200 symulacji Monte-Carlo \\ w programie MATLAB/Simulink w celu zbadania zachowania pocisku w fazie startu z użyciem \\ zmierzonych wartości. Zostało zaobserwowane, że moment przechylający wynikający \\ m.in. z niedokładności montażowych stabilizatorów wpływa znacząco na uzyskiwane trajektorie.
}




\section{Rafał Ożóg, MSc}

rozog@meil.pw.edu.pl

ORCID: 0000-0002-5703-8830

Graduated (2016) from the Warsaw University of Technology. He is a PhD candidate at Faculty of Power and Aeronautical Engineering. His research interests are: unmanned aerial vehicles, control theory and Arduino programming.

\section{Mariusz Jacewicz, MSc}

mjacewicz@meil.pw.edu.p ORCID: 0000-0002-7173-0890

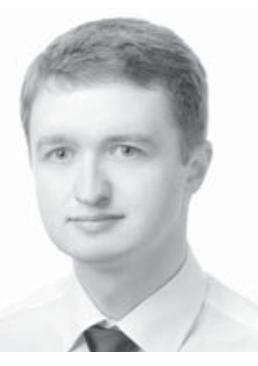

Graduated (2015) from the Warsaw University of Technology. He is a PhD student at Faculty of Power and Aeronautical Engineering of WUT. His research interests include: modeling and simulation, control theory and missile systems engineering.

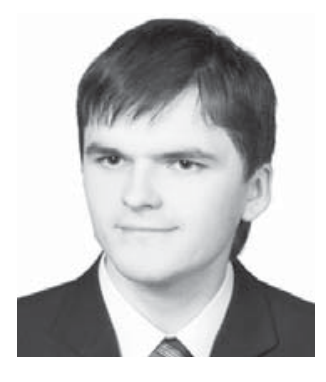

\section{Prof. Robert Głębocki, DSc. PhD}

rglebocki@meil.pw.edu.p

ORCID: 0000-0002-2389-7653

Professor of Warsaw University of Techno-

logy - Faculty of Power and Aeronautical Engineering. His research activity fields are: control systems, aeronautics, UAV, space, military mobile systems, missiles control Author of two books and about one hundred papers in journals and conference proceedings. Consulting services and cooperation with Polish and international aircraft

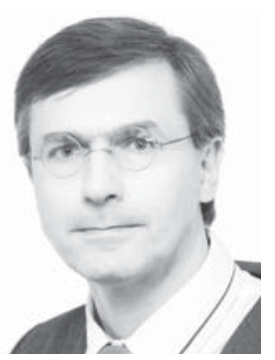
military and space industry. 